\title{
Ni-catalyzed reductive amination of phenols with ammonia or amines into cyclohexylamines
}

Received 00th January 20xx, Accepted 00th January 20xx DOI: $10.1039 / x 0 x \times 00000 x$

\author{
Thomas Cuypers, Thomas Morias, Simon Windels, Carlos Marquez, Cédric Van Goethem, Ivo \\ Vankelecom and Dirk E. De Vos*
}

\begin{abstract}
Phenol and its derivatives, which naturally occur in lignocellulose, can be considered as a renewable feedstock not only for aromatic, but also for alicyclic compounds, such as primary and $N$-substituted cyclohexylamines. So far, the latter are mostly produced from non-renewable starting materials like benzene via problematic nitration/reduction or cross-coupling routes. Herein, an efficient reductive amination of phenol with ammonia or amines is demonstrated, for the first time without the need for rare and expensive noble metals and without using any additives. Various supported Ni catalysts were screened and we elucidated the influence of the key parameters, including the acid-base properties of the supporting material. Acquired knowledge was then applied to different phenol-ammonia/amine combinations, resulting in the synthesis of various primary, secondary and tertiary cyclohexylamines in fair to very high yields.
\end{abstract}

\section{Introduction}

A wide range of important chemical precursors are nowadays produced from primary or $\mathrm{N}$-substituted cyclohexylamines, including electronic materials, vulcanization accelerators, pharmaceuticals, agrochemicals and polymers. ${ }^{1-4}$ Hence, the development of green and efficient pathways towards these aliphatic amines becomes essential regarding the evolution to a more sustainable chemical industry. Present-day production routes, predominantly via hydrogenation of nitroarenes ${ }^{5-9}$ and anilines $^{10-12}$ (in the gas phase), require pre-functionalized starting materials which are typically obtained from nonrenewable petrochemical sources through multi-step processes. ${ }^{13-17}$ Moreover, these routes suffer from several other technological disadvantages such as the generation of hazardous waste streams, low atom and energy efficiency. ${ }^{18}$ Phenols, on the other hand, are an interesting class of alternative starting materials and are naturally present in the structure of renewable lignocellulosic biomass (i.e., lignin); ${ }^{19}$ but they are also efficiently available at low price from fossil sources to accommodate for the immediate industrial need. ${ }^{20}$ Recently, $N$-substituted cyclohexylamines ${ }^{21-23}$ and $N$ substituted anilines ${ }^{24,25}$ were produced via the (reductive) amination of phenol with amines in the liquid phase. Here, phenol is partially reduced to cyclohexanone in the presence of a supported $\mathrm{Pd}$ catalyst and a hydrogen source (e.g., $\mathrm{H}_{2}, \mathrm{NaBH}_{4}$ or $\mathrm{HCO}_{2} \mathrm{Na}$ ), which then reacts with an amine towards a

Centre for Membrane Separations, Adsorption, Catalysis and Spectroscopy (cMACS), KU Leuven - University of Leuven, Celestijnenlaan 200F, Post Box 2461, 3001 Heverlee, Belgium. E-mail: dirk.devos@kuleuven.be

†Electronic Supplementary Information (ESI) available: Experimental details, additional reactions, XRD, SEM, STEM, EDX, $\mathrm{N}_{2}$ physisorption, $\mathrm{NH}_{3}$ solubility experiments, FTIR and product identification. See DOI: 10.1039/x0xx00000x cyclohexanimine intermediate. This imine is then either hydrogenated further or dehydrogenated to the desired product, depending on the employed reaction conditions.

In spite of this, the production of primary cyclohexylamines and anilines from phenol remained a difficult challenge until our group reported that these compounds could be efficiently produced by employing a commercial $\mathrm{Rh}$ or $\mathrm{Pd} / \mathrm{C}$ catalyst, respectively, in the presence of $\mathrm{H}_{2}$ and $\mathrm{NH}_{3}$ without the use of any additives. ${ }^{26,27}$ More recently, hydrazine was suggested as both the amine and hydride source. ${ }^{28}$ So far, no protocols relate to the substitution of these precious metals by more earthabundant metals such as $\mathrm{Ni}$, even though the use of this metal is well established in the chemical industry. Based on related $\mathrm{Ni}$ catalyzed reactions, ${ }^{29-35}$ we hypothesized that a sufficient amount of the cyclohexanone intermediate might be formed in the course of the reaction, which in turn could afford primary or $\mathrm{N}$-substituted cyclohexylamines in the presence of ammonia or amines, respectively. Moreover, the effect of the acid-base properties of the supporting material remains unclear, as only commercially available $\mathrm{Rh}$ or Pd on carbon catalysts were used so far. Herein, we present the direct $\mathrm{Ni}$-catalyzed reductive amination of phenols with ammonia or amines into primary, secondary or tertiary cyclohexylamines (Scheme 1).

Reductive amination of (renewable) phenols

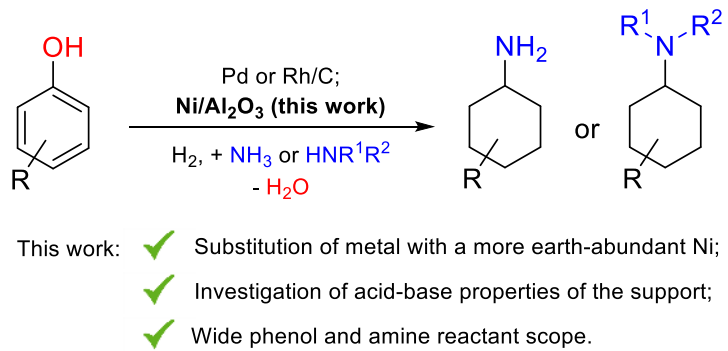

Scheme 1. Synthesis of primary, secondary or tertiary cyclohexylamines from phenols. 


\section{Results and discussion}

\section{Catalyst and solvent screening}

In a first set of exploratory reactions, several self-prepared supported nickel catalysts were screened for the direct amination of phenol (1a) with ammonia (2a) (Table 1). Reaction conditions based on our previous work were employed. ${ }^{26,27}$ While $\mathrm{Ni}$ supported on $\mathrm{Nb}_{2} \mathrm{O}_{5}$ gave no activity at all $(10 \mathrm{~mol} \% \mathrm{Ni}$, toluene, $3 \mathrm{~h}$ at $160{ }^{\circ} \mathrm{C}, 4$ bar $\mathrm{H}_{2}$ and 0.5 bar $\mathrm{NH}_{3}$; entry 1 ), all other catalysts formed cyclohexylamine (3a) with a very high selectivity ( $\geq 90 \%$ ) and with cyclohexanol as the only significant by-product, regardless of the supporting material. The conversion of phenol, however, varied considerably with the choice of the support. $\mathrm{Ni}$ on $\mathrm{TiO}_{2}, \mathrm{SiO}_{2}$ and $\mathrm{SiO}_{2}-\mathrm{Al}_{2} \mathrm{O}_{3}$ displayed a very low phenol conversion $(\leq 14 \%)$, while $\mathrm{Ni} / \mathrm{ZrO}_{2}$ exhibited a moderate activity (entries 2-5). The self-prepared spinel-type materials performed better and reached cyclohexylamine yields up to $85 \%$ (entries $6-8$ ). Interestingly, such result was obtained

Table 1. Screening of supported Ni-catalysts and solvent for the direct amination of phenol with ammonia to cyclohexylamine. ${ }^{[a]}$

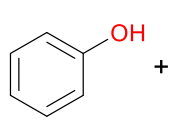

$1 \mathbf{a}$

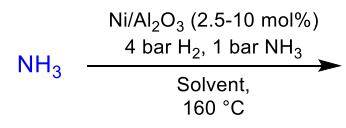

$2 a$

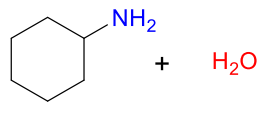

$3 \mathbf{a}$

\begin{tabular}{|c|c|c|c|c|}
\hline Entry & Catalyst & Solvent & $X[\%]$ & $\mathrm{Y}_{\mathrm{CHA}}\left(\mathrm{S}_{\mathrm{CHA}}\right)[\%]$ \\
\hline 1 & $\mathrm{Ni} / \mathrm{Nb}_{2} \mathrm{O}_{5}$ & Toluene & n.r. & - \\
\hline 2 & $\mathrm{Ni} / \mathrm{TiO}_{2}$ & Toluene & 4 & 4 (>99) \\
\hline 3 & $\mathrm{Ni} / \mathrm{SiO}_{2}$ & Toluene & 3 & $3(>99)$ \\
\hline 4 & $\mathrm{Ni} / \mathrm{SiO}_{2}-\mathrm{Al}_{2} \mathrm{O}_{3}$ & Toluene & 14 & 13 (>99) \\
\hline 5 & $\mathrm{Ni} / \mathrm{ZrO}_{2}$ & Toluene & 50 & $46(91)$ \\
\hline 6 & $\mathrm{Ni} / \mathrm{BaAl}_{2} \mathrm{O}_{4}$ & Toluene & 58 & $52(90)$ \\
\hline 7 & $\mathrm{Ni} / \mathrm{CaAl}{ }_{2} \mathrm{O}_{4}$ & Toluene & 60 & $56(94)$ \\
\hline 8 & $\mathrm{Ni} / \mathrm{MgAl}_{2} \mathrm{O}_{4}$ & Toluene & 93 & $85(92)$ \\
\hline 9 & $\mathrm{Ni} / \gamma-\mathrm{Al}_{2} \mathrm{O}_{3}$ & Toluene & 84 & $81(97)$ \\
\hline 10 & $\mathrm{Ni} / \mathrm{Al}_{2} \mathrm{O}_{3}$ & Toluene & $>99$ & 99 (99) \\
\hline $11^{[b]}$ & $\mathrm{Ni} / \mathrm{Al}_{2} \mathrm{O}_{3}$ & Toluene & $>99$ & 97 (97) \\
\hline $12^{[c]}$ & $\mathrm{Ni} / \mathrm{Al}_{2} \mathrm{O}_{3}$ & Toluene & 78 & $69(88)$ \\
\hline $13^{[d]}$ & $\mathrm{Ni} / \mathrm{Al}_{2} \mathrm{O}_{3}$ & Toluene & 27 & $26(94)$ \\
\hline $14^{[c]}$ & $\mathrm{Ni} / \mathrm{Al}_{2} \mathrm{O}_{3}$ & TAA & n.r. & - \\
\hline $15^{[c]}$ & $\mathrm{Ni} / \mathrm{Al}_{2} \mathrm{O}_{3}$ & Methanol & n.r. & - \\
\hline $16^{[c]}$ & $\mathrm{Ni} / \mathrm{Al}_{2} \mathrm{O}_{3}$ & 2-Propanol & n.r. & - \\
\hline $17^{[c]}$ & $\mathrm{Ni} / \mathrm{Al}_{2} \mathrm{O}_{3}$ & TAME & 63 & $59(93)$ \\
\hline $18^{[c]}$ & $\mathrm{Ni} / \mathrm{Al}_{2} \mathrm{O}_{3}$ & CPME & 42 & $36(85)$ \\
\hline $19^{[c]}$ & $\mathrm{Ni} / \mathrm{Al}_{2} \mathrm{O}_{3}$ & 2-MeTHF & 12 & $8(68)$ \\
\hline $20^{[c]}$ & $\mathrm{Ni} / \mathrm{Al}_{2} \mathrm{O}_{3}$ & $\mathrm{MeCH}$ & 79 & $71(90)$ \\
\hline
\end{tabular}

[a] Reaction conditions: phenol (1a, $2 \mathrm{mmol}$ ) in solvent ( $20 \mathrm{~mL}), 10 \mathrm{~mol} \% \mathrm{Ni}(5 \mathrm{wt} \% \mathrm{Ni}$ on support), 4 bar $\mathrm{H}_{2}$ and 1 bar $\mathrm{NH}_{3}$ (2a) for $3 \mathrm{~h}$ at $160{ }^{\circ} \mathrm{C}$. CHA: cyclohexylamine (3a) $\mathrm{MeCH}$ : methylcyclohexane, TAA: tert-amyl alcohol, TAME: tert-amyl methyl ether, CPME: cyclopentyl methyl ether, 2-MeTHF: 2-methyltetrahydrofuran. Conversions (X), yields $(\mathrm{Y})$ and selectivities (S) were determined by GC-FID analysis with $\mathrm{n}$-nonane as the external standard. [b] phenol $(1 \mathrm{a}, 50 \mathrm{mmol})$ in toluene $(100 \mathrm{~mL}), 10 \mathrm{~mol} \% \mathrm{Ni}$ for $6 \mathrm{~h}$. [c] $5 \mathrm{~mol} \% \mathrm{Ni} / \mathrm{Al}_{2} \mathrm{O}_{3}$. [d] $2.5 \mathrm{~mol} \% \mathrm{Ni} / \mathrm{Al}_{2} \mathrm{O}_{3}$. using a $\mathrm{Ni} / \mathrm{MgAl}_{2} \mathrm{O}_{4}$ catalyst that was activated at a reduction temperature of $600{ }^{\circ} \mathrm{C}$, which is lower than typically reported in literature. ${ }^{36}$ The more commonly used activation procedure, viz. reduction of $\mathrm{Ni} / \mathrm{MgAl}_{2} \mathrm{O}_{4}$ at $800{ }^{\circ} \mathrm{C}$, resulted in a significant drop in phenol conversion (Table S1, entries 1-3) which may be attributed to the sintering of $\mathrm{Ni}$ particles. Next, Ni supported on $\mathrm{\gamma}-\mathrm{Al}_{2} \mathrm{O}_{3}$ and $\mathrm{Al}_{2} \mathrm{O}_{3}$ was evaluated (entries 9-10). Full conversion of phenol was obtained using the latter, resulting in a cyclohexylamine yield of $99 \%$. The reductive amination was then performed at a larger scale by increasing both the reaction volume $(100 \mathrm{~mL})$ and substrate concentration $(0.5 \mathrm{M}$ phenol). Compared to the original conditions, a nearly identical cyclohexylamine yield (97\%) was obtained after $6 \mathrm{~h}$ of reaction (entry 11). The catalyst loading was then lowered (entries 1213), which resulted in a significant drop in phenol conversion, while maintaining a very high selectivity towards to the desired product. Using $5 \mathrm{~mol} \% \mathrm{Ni} / \mathrm{Al}_{2} \mathrm{O}_{3}$ with respect to phenol, a cyclohexylamine yield of $69 \%$ was observed and this result was used as a benchmark for further optimization of the reaction parameters.

In addition to toluene, other solvents were tested. Solvents are ideally green of nature, must remain stable under the employed reaction conditions and ought to sufficiently dissolve phenol and ammonia. $Y$-Valerolactone and propylene carbonate undergo undesired ring-opening with ammonia, ${ }^{37}$ which renders them unsuitable for the reaction. Even though tert-amyl alcohol (TAA), 2-propanol and methanol were already established as excellent solvents in our previous work for direct amination of phenol using $\mathrm{Pd}$ - or $\mathrm{Rh} / \mathrm{C}$ catalysts, it was found that these solvents are incompatible with Ni-supported catalysts as no reaction took place (entries 14-16). Moreover, undesired reductive amination of 2-propanol and alkylation of ammonia with methanol occurred. The lack of activity of $\mathrm{Ni}$ in these solvents could be explained by the strong interaction of the hydroxyl group of these protic solvents with the metal and a higher solubility of ammonia (Figure S1), which might contribute to the inhibition of the catalyst. Aprotic polar solvents such as tert-amyl methyl ether (TAME), cyclopentyl methyl ether (CPME) and 2-methyltetrahydrofuran (2-MeTHF) - green alternative solvents for toluene 38,39 - remained stable in the presence of ammonia. Low to moderate cyclohexylamine yields (especially in TAME) were obtained (entries 17-19), albeit not surpassing the benchmark reaction in toluene. One could argue that both toluene ( $v i a$-interaction with the aromatic ring) and phenol could compete for a limited number of active $\mathrm{Ni}$-sites available on the surface of the catalyst, resulting in a lower cyclohexylamine yield. Only limited hydrogenation of the aromatic ring of toluene occurred in these reactions $1<0.05$ vol\% with respect to toluene), which at the most hints at a limited interaction with the catalyst. The use of methylcyclohexane $(\mathrm{MeCH})$ was also explored. Even though a cyclohexylamine yield of $71 \%$ was obtained, it did not significantly improve the formation of the desired product compared to the reaction in toluene (entry 20 vs 11$)$. Moreover, phenol is not very soluble in $\mathrm{MeCH}(<0.5 \mathrm{M})$, which could be problematic in the context of industrial applicability. 
It became clear from the catalyst screening reactions that $\mathrm{Ni}$ supported on, for example, $\mathrm{ZrO}_{2}, \mathrm{MgAl}_{2} \mathrm{O}_{4}$ and $\mathrm{Al}_{2} \mathrm{O}_{3}$ performed noticeably better than $\mathrm{Ni}$ on $\mathrm{SiO}_{2}$, or $\mathrm{Ni}$ on $\mathrm{Nb}_{2} \mathrm{O}_{5}, \mathrm{TiO}_{2}$ and $\mathrm{SiO}_{2}-$ $\mathrm{Al}_{2} \mathrm{O}_{3}$. These differences could be related to the acid-base properties of the support as ammonia and primary amines, just like the desired cyclohexylamine product, are known to interact with active sites, thereby possibly influencing the activity of the catalyst. Indeed, $\mathrm{Nb}_{2} \mathrm{O}_{5}, \mathrm{TiO}_{2}$ and $\mathrm{SiO}_{2}-\mathrm{Al}_{2} \mathrm{O}_{3}$ have been classified as highly acidic materials based on spectroscopic characterization, and a too strong adsorption of amine reactants or products on the support could result in inhibition of the Ni activity. ${ }^{40-42}$ It should be noted, however, that some acidity is necessary to assist the hydrogenation of phenol and the condensation of cyclohexanone with ammonia. This would explain the poor activity of an essentially neutral support such as $\mathrm{SiO}_{2} .{ }^{42}$ For the materials with an expected moderate acidity $\left(\mathrm{MgAl}_{2} \mathrm{O}_{4}, \mathrm{Al}_{2} \mathrm{O}_{3}\right.$ and $\left.\mathrm{ZrO}_{2}\right)$, the interactions between the amine and the support were investigated by Fourier-transform infrared (FTIR) spectroscopy using cyclohexylamine as the probe molecule. After adsorption of the probe and evacuation of the physisorbed molecules at $50{ }^{\circ} \mathrm{C}$, the expected bands representing the vibrational modes of cyclohexylamine were present (Table 2). Absorption bands due to the asymmetric and symmetric stretching of $\mathrm{C}-\mathrm{H}$ bonds appeared at wavenumbers between 2943-2858 $\mathrm{cm}^{-1}$, while $\mathrm{CH}$ and $\mathrm{CH}_{2}$ deformations were observed below $1500 \mathrm{~cm}^{-1}$. Very weak and broad $\mathrm{N}-\mathrm{H}$ stretching bands, characteristic for the amino group of primary amines, appeared at wavenumbers above $3200 \mathrm{~cm}^{-1}$ for $\mathrm{Al}_{2} \mathrm{O}_{3}$ and $\mathrm{ZrO}_{2}$, but were too weak and broad to be observed for $\mathrm{MgAl}_{2} \mathrm{O}_{4}$. They were accompanied by sharper and relatively stronger bands at $1590 \mathrm{~cm}^{-1}$ for $\mathrm{MgAl}_{2} \mathrm{O}_{4}$ and $\mathrm{Al}_{2} \mathrm{O}_{3}$, and at a slightly lower wavenumber (viz., $1583 \mathrm{~cm}^{-1}$ ) for the $\mathrm{ZrO}_{2}$ support, typical for the $\mathrm{NH}_{2}$ deformation mode of the primary amine. Generally, shift of these bands to lower wavenumbers suggests a stronger interaction of cyclohexylamine with the acid sites of the catalyst. ${ }^{40,43}$ Thus, the interaction of the amine with the surface seems to increase in the order $\mathrm{MgAl}_{2} \mathrm{O}_{4} \approx \mathrm{Al}_{2} \mathrm{O}_{3}<\mathrm{ZrO}_{2}$.

As visualized in Figure 1, similar trends were observed during the temperature programmed desorption (TPD) experiments. Overall, the $\delta\left(\mathrm{NH}_{2}\right)$ bands of cyclohexylamine decreased in intensity and the signal maximum of this vibration shifted to lower wavenumbers upon increasing the temperature from $50{ }^{\circ} \mathrm{C}$ to $250{ }^{\circ} \mathrm{C}$. This observation relates to
Table 2. Characteristic FTIR bands (in $\mathrm{cm}^{-1}$ ) observed after adsorption of cyclohexylamine at $50{ }^{\circ} \mathrm{C}$ on $\mathrm{MgAl}_{2} \mathrm{O}_{4}, \mathrm{Al}_{2} \mathrm{O}_{3}$ and $\mathrm{ZrO}_{2}$.

\begin{tabular}{|c|c|c|c|}
\hline Vibration mode & $\mathrm{MgAl}_{2} \mathrm{O}_{4}$ & $\mathrm{Al}_{2} \mathrm{O}_{3}$ & $\mathrm{ZrO}_{2}$ \\
\hline \multirow{2}{*}{$v(N-H)$} & - & $3332(w)$ & $3320(w)$ \\
\hline & - & $3260(w)$ & $3233(w)$ \\
\hline \multirow{5}{*}{$v(C-H)$} & $2940(\mathrm{~m})$ & $2942(\mathrm{~m})$ & $2943(\mathrm{~m})$ \\
\hline & $2933(\mathrm{~s})$ & 2936 (s) & $2938(\mathrm{~s})$ \\
\hline & $2925(\mathrm{~m})$ & $2932(\mathrm{~m})$ & 2931 (s) \\
\hline & $2921(\mathrm{~m})$ & $2922(\mathrm{~m})$ & $2923(\mathrm{~s})$ \\
\hline & $2858(\mathrm{~s})$ & $2860(\mathrm{~s})$ & $2859(\mathrm{~s})$ \\
\hline$\delta\left(\mathrm{NH}_{2}\right)$ & $1590(\mathrm{~m})$ & $1591(\mathrm{~m})$ & $1583(\mathrm{~m})$ \\
\hline \multirow{2}{*}{$\delta\left(\mathrm{CH}, \mathrm{CH}_{2}\right)$} & 1453 (s) & $1453(\mathrm{~s})$ & 1452 (s) \\
\hline & $1348(w)$ & $1349(w)$ & $1358(w)$ \\
\hline
\end{tabular}

the desorption of cyclohexylamine from the weaker acid sites of the catalyst. Expectedly, this decrease in absorbance was the least pronounced for $\mathrm{ZrO}_{2}$ (c) as the amine interacts more strongly with this support. This is also an indication of the stronger acidity of $\mathrm{ZrO}_{2}$ compared to that of $\mathrm{MgAl}_{2} \mathrm{O}_{4}$ and $\mathrm{Al}_{2} \mathrm{O}_{3}$ (a and b). For $\mathrm{ZrO}_{2}$ at $250{ }^{\circ} \mathrm{C}$, a clear band appears at $\sim 1486 \mathrm{~cm}^{-}$ 1 which could be assigned to the $\mathrm{C}=\mathrm{C}$ stretching of aniline, resulting from a Lewis acid-catalyzed dehydrogenation, as saturated $\mathrm{ZrO}_{2}$ sample (Figure S2). An additional, rather broad temperatures. ${ }^{44}$ The attribution of this band to aniline was reported for $\mathrm{Al}_{2} \mathrm{O}_{3}$ by other researchers, albeit at slightly higher signal at $\sim 1551 \mathrm{~cm}^{-1}$, which was only observed at $250{ }^{\circ} \mathrm{C}$ and as a slight shoulder at $150{ }^{\circ} \mathrm{C}$, might originate from the vibration modes of cyclohexanimine, as the characteristic $\mathrm{C}=\mathrm{C}$ stretching modes ( 1620-1680 $\left.\mathrm{cm}^{-1}\right)$ of other partially dehydrogenated species (viz., alkenes) were not observed.

Based on these findings, we conclude that the moderate activity of $\mathrm{Ni} / \mathrm{ZrO}_{2}$ is explained by strong adsorption of the cyclohexylamine product, or of the slightly less basic $\mathrm{NH}_{3}$ reactant, ${ }^{45}$ on the acidic sites of the support. As a result, a catalyst inhibition effect could take place, which would be detrimental for the hydrogenation capabilities of the $\mathrm{Ni}$ catalyst. Similarly, we presume that this occurs to an even higher extent

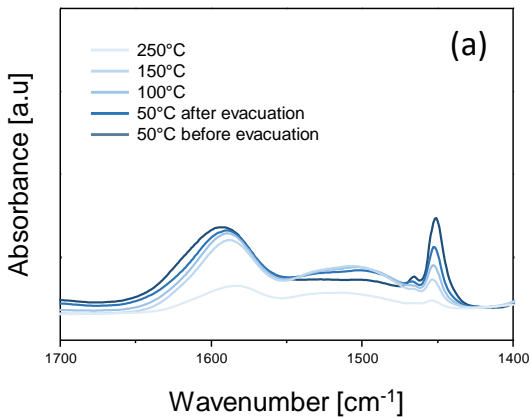

Wavenumber $\left[\mathrm{cm}^{-1}\right]$

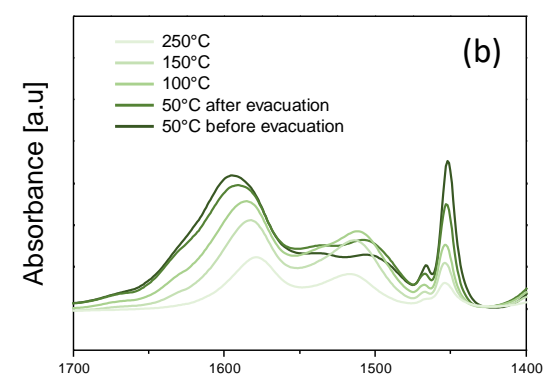

Wavenumber $\left[\mathrm{cm}^{-1}\right]$

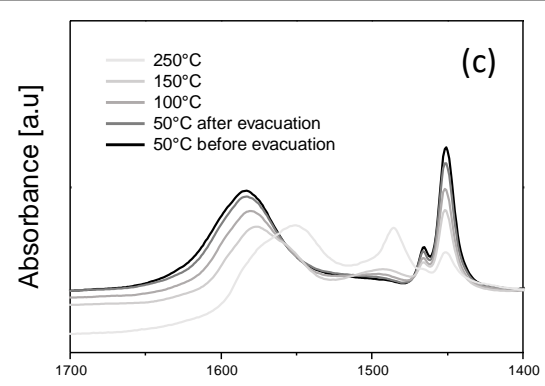

Wavenumber $\left[\mathrm{cm}^{-1}\right]$ 
Figure 1. Difference FTIR spectra recorded during temperature programmed desorption (TPD) of cyclohexylamine on self-supported wafers of (a) $\mathrm{MgAl}_{2} \mathrm{O}_{4}$, (b) $\mathrm{Al}_{2} \mathrm{O}_{3}$ and (c) $\mathrm{ZrO}_{2}$ normalized to $10 \mathrm{mg}$ of sample per $\mathrm{cm}^{2}$.

for $\mathrm{Ni}$ supported on highly acidic $\mathrm{Nb}_{2} \mathrm{O}_{5}, \mathrm{TiO}_{2}$ and $\mathrm{SiO}_{2}-\mathrm{Al}_{2} \mathrm{O}_{3}$. $\mathrm{MgAl}_{2} \mathrm{O}_{4}$ and $\mathrm{Al}_{2} \mathrm{O}_{3}$ possess only a moderate acidity; consequently, the $\mathrm{N}$-containing compounds do not interact so strongly with the support. Finally, $\mathrm{Ni} / \mathrm{SiO}_{2}$ might lack the acidity necessary to sufficiently catalyzed some reaction steps. Similar findings regarding the influence of the acidity of the supporting material on the activity were made for supported $\mathrm{Pd}$ and $\mathrm{Rh}$ catalysts; these results are discussed in the supporting information (Table S1, entries 4-9).

\section{Tentative mechanism}

In an ideal reaction, visualized by the scheme in Figure 2, phenol (1) is first partially reduced to 1-cyclohexenol which undergoes enol-keto tautomerization to cyclohexanone (2). ${ }^{46,47}$ In our prior reports, we found that polar solvents can aid in the proton transfer needed for this tautomerization; but in the case of $\mathrm{Ni}$ catalysts, Ni might interact too strongly with protic solvents and hamper the hydrogenation activity. Next, acid-catalyzed condensation of cyclohexanone with ammonia gives rise to cyclohexanimine (3). A similar reaction pathway through imine, iminium ion or enamine intermediates could be proposed when primary or secondary amines are used instead of ammonia. Further hydrogenation of the imine results in the formation of the desired cyclohexylamine (4). As both $\mathbf{2}$ and $\mathbf{3}$ are reactive intermediates undesired condensation with the amine product could occur, resulting in secondary amines (i.e., dicyclohexylamine, 5); this side reaction is more prominent for the reactions using $\mathrm{Pd}$ catalysts (Table S1). Also, deep hydrogenation of $\mathbf{2}$ can result in the reversible formation of cyclohexanol (6). For the reactions using $\mathrm{Ni}$ as the catalyst, no unsaturated products such as aniline, $\mathrm{N}$-cyclohexylaniline or diphenylamine were obtained in meaningful yields.

\section{Optimization of reaction conditions}

The system was then optimized using $5 \mathrm{~mol} \% \mathrm{Ni} / \mathrm{Al}_{2} \mathrm{O}_{3}$ by varying both $\mathrm{NH}_{3}$ and $\mathrm{H}_{2}$ partial pressures. As visualized in Figure 3 , the highest phenol conversion ( $v i z ., 91 \%$ ) was realized at 0.5 bar $\mathrm{NH}_{3}$, which corresponds to around 7 equivalents of dissolved $\mathrm{NH}_{3}$ in solution with respect to phenol, significantly improving the yield of cyclohexylamine up to $83 \%$. At even lower pressures, the cyclohexylamine yield dropped noticeably which can be attributed to a slower hydrogenation of phenol.

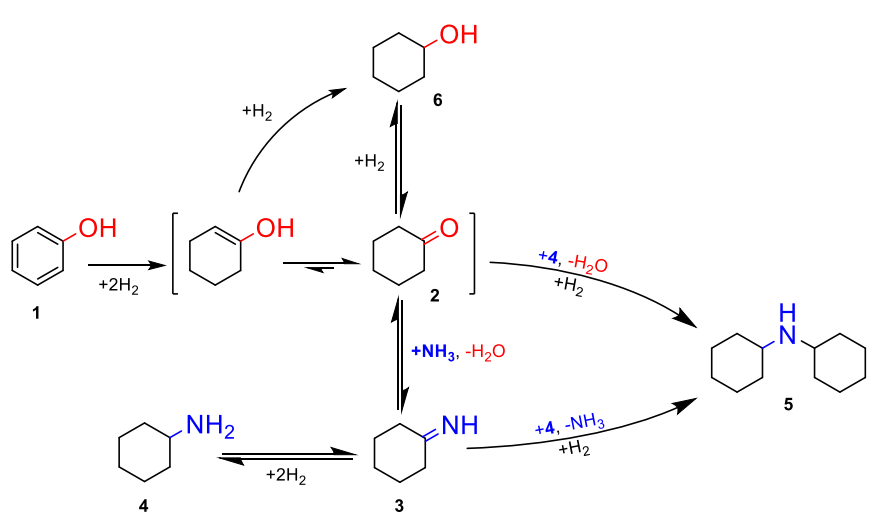

Figure 2. Reaction mechanism for the reductive amination of phenol with ammonia.

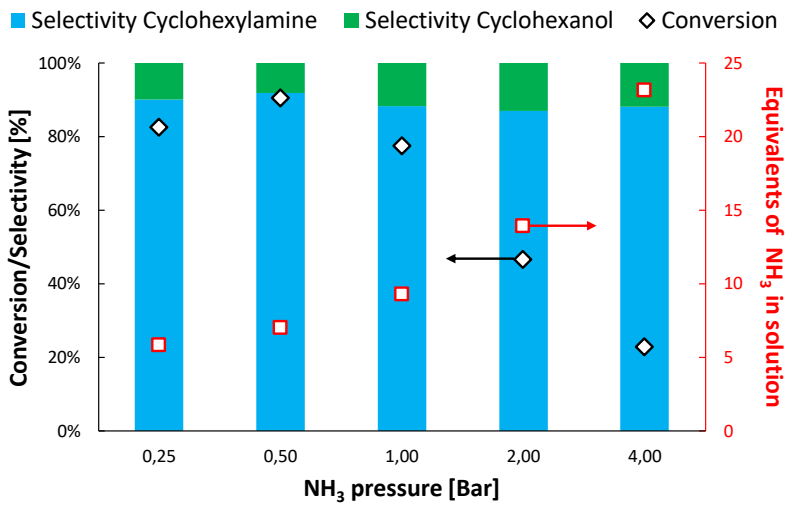

Figure 3. Influence of the $\mathrm{NH}_{3}$ partial pressure on the reductive amination of phenol with ammonia. Reaction conditions: phenol $(2 \mathrm{mmol})$ in solvent $(20 \mathrm{~mL}), 5 \mathrm{~mol} \% \mathrm{Ni} / \mathrm{Al}_{2} \mathrm{O}_{3}$, 4 bar $\mathrm{H}_{2}$ for $3 \mathrm{~h}$ at $160^{\circ} \mathrm{C}$.

As the overall reaction pathway proceeds through multiple equilibria, a slow reaction of cyclohexanone and ammonia to cyclohexanimine could limit phenol conversion. To demonstrate this, a reaction in the absence of ammonia was performed which indeed resulted in a lower phenol conversion (81\%). Furthermore, the selectivity towards cyclohexanone was rather low (24\%), which can be expected as it is known that phenol is selectively hydrogenated to cyclohexanol in the presence of $\mathrm{Ni}$ under reducing conditions. ${ }^{33,34}$ As a result, the addition of ammonia does not only improve phenol conversion, but also shifts the cyclohexanone/cyclohexanol equilibrium to the more reactive ketone. At higher ammonia partial pressures, phenol conversion dropped steadily from $91 \%$ at 0.5 bar $\mathrm{NH}_{3}$ down to only $23 \%$ at 4 bar $\mathrm{NH}_{3}$. Ammonia and amines are known to interact with the active sites of catalysts. ${ }^{30}$ As a result, an inhibiting effect on the catalyst at high $\mathrm{NH}_{3}$ concentrations could occur by a strong interaction with $\mathrm{Ni}$ or acid sites (vide supra), which are both necessary for the reaction, leading to a drop in phenol conversion. For all reactions, cyclohexylamine selectivity shifted only slightly between $87-92 \%$ and no formation of secondary amines (e.g., dicyclohexylamine) was observed, even at low $\mathrm{NH}_{3}$ partial pressures. The high selectivity 
of $\mathrm{Ni}$ towards primary amines is quite remarkable as significant amounts of secondary or even tertiary amines are usually obtained in related reactions using Pd catalysts. ${ }^{26,48-51}$

$\mathrm{Next}$, it was found that changing the $\mathrm{H}_{2}$ partial pressure drastically affected the conversion, increasing from only $20 \%$ at 1 bar $\mathrm{H}_{2}$ to full conversion at 8 bar $\mathrm{H}_{2}$ (Figure 4). While the selectivity for cyclohexanol in these reactions increased only slightly with the $\mathrm{H}_{2}$ pressure, undesired deep hydrogenation of phenol was more noticeable at even higher pressures (16 bar $\mathrm{H}_{2}$ ). Also for latter reaction, hydrogenation of the solvent to methylcyclohexane was limited $(<0.15$ vol\%).

\section{Phenol reactant scope}

After establishing the optimized reaction conditions, various substituted phenols were evaluated for the direct liquid-phase reductive amination with ammonia to investigate the effect of the substituents on the reactivity, using $10 \mathrm{~mol} \%$ of $\mathrm{Ni} / \mathrm{Al}_{2} \mathrm{O}_{3}$ (Table 2). For $o^{-}, m$ - and $p$-cresol, the presence of a methyl

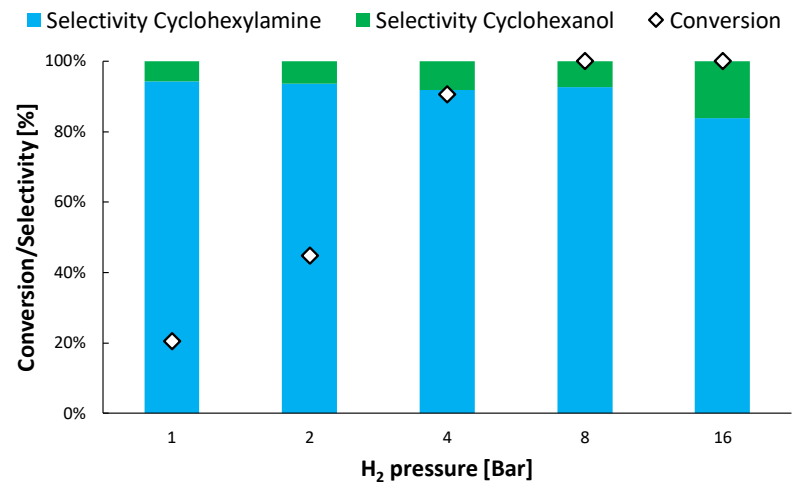

Figure 4. Influence of the $\mathrm{H}_{2}$ partial pressure on the reductive amination of phenol with ammonia. Reaction conditions: phenol $(2 \mathrm{mmol})$ in solvent $(20 \mathrm{~mL}), 5 \mathrm{~mol} \% \mathrm{Ni} / \mathrm{Al}_{2} \mathrm{O}_{3}$, 0.5 bar $\mathrm{NH}_{3}$ for $3 \mathrm{~h}$ at $160^{\circ} \mathrm{C}$.

group on the aromatic ring slowed down the reaction due to sterical hindrance in the order of para < meta < ortho; but the reactions still resulted in good to high yields of the corresponding methylcyclohexylamines after only $3 \mathrm{~h}$ (3b-d). As previously reported by $\mathrm{Xu}$ et al., 52 substrates with bulkier substituents - such as 4-n-propyl and 4-tert-butyl groups slowed down the hydrogenation of phenol derivatives even more drastically; these reactions afforded the corresponding cyclohexylamines with a very high selectivity of $\geq 99 \%$ in the presence of ammonia (3e and f). 4-n-Propylphenol is one of the main reductive fractionation products derived from lignin ${ }^{53,54}$ and its use, therefore, is very attractive in the context of green chemistry. High yields of the aforementioned alkyl cyclohexylamines were obtained at full substrate conversion by simply increasing the reaction time to $6 \mathrm{~h}$ or $16 \mathrm{~h}$. Similarly, the presence of a methoxy group on the aromatic ring negatively affected the conversion of the phenolic substrate $(\mathbf{3 g}-\mathbf{i})$. For the reductive amination of 2-methoxyphenol, the formation of a slightly discolored green-blue reaction mixture was observed from which a precipitate started to form; and 2methoxycyclohexylamine $\mathbf{( 3 g}$ ) was only obtained in a very low yield $(\sim 4 \%)$ after $16 \mathrm{~h}$. As a result of these observations, we speculate that Ni might coordinate with the bidentate phenolic reactant and leach into the solution, as was confirmed by ICPOES. In contrast, for all other reactions, no color change of the solution was observed and ICP analyses of selected reactions revealed that the $\mathrm{Ni}$ content in the filtrate was below the detection limit of $0.03 \mathrm{wt} \% \mathrm{Ni}$ leaching from the catalyst. Both 3-methoxyphenol and 4-methoxyphenol afforded the desired product ( $3 \mathrm{~h}$ and $\mathrm{i}$ ) at full substrate conversion after $6 \mathrm{~h}$ and $3 \mathrm{~h}$ of reaction, respectively. For the former substrate, however, significant amounts of cyclohexylamine (41\%) were formed, which drastically reduced the selectivity towards the desired product. In prior related reports, this reaction was explained by demethoxylation (via $\beta$-elimination) of the 3methoxycyclohexanone intermediate, followed by hydrogenation of the resulting $\mathrm{C}=\mathrm{C}$ double bond of 2cyclohexenone. ${ }^{21,23,55}$ The structure of lignin contains a large number of $\mathrm{C}-\mathrm{O}$ ether bonds, including $4-0-5$ and $\alpha-0-4$ linkages. ${ }^{19}$ As a result, diphenyl ether and benzyl phenyl ether

Table 2. Reductive amination of various substituted phenols with ammonia. ${ }^{[a]}$

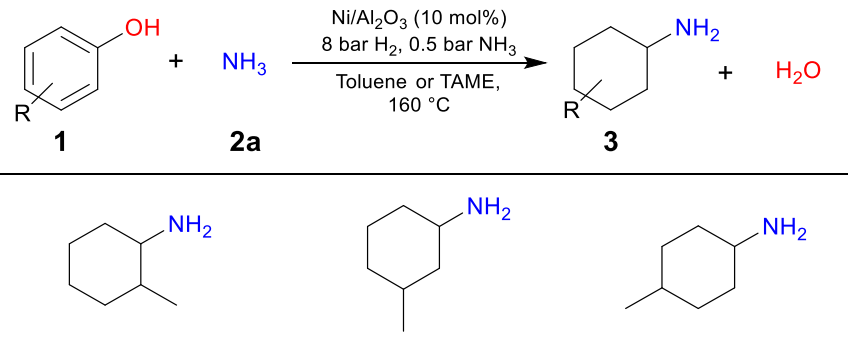

3b, 68\% (c:t 77:23) $97 \%(c: t 76: 24)^{[b]}$

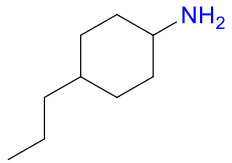

3e, 69\% (c:t 73:27) $97 \%(c: t 69: 31)^{[b]}$<smiles>COC1CCCC(N)C1</smiles>

3h, 53\% (c:t 55:45) $)^{[b]}$<smiles>NC1CCCCC1</smiles>

3c, $80 \%$ (c:t 76:24) $97 \%(c: t 73: 27)^{[b]}$<smiles>CC(C)(C)C1CCC(N)CC1</smiles>

3f, $32 \%$ (c:t $82: 18$ ) $96 \%(c: t 73: 27)^{[c]}$<smiles>COC1CCC(N)CC1</smiles>

3i, $92 \%$ (c:t 57:43) 3d, $89 \%$ (c:t 74:26) $96 \%$ (c:t $72: 28)^{[b]}$<smiles>COC1CCCCC1N</smiles>

$3 g, 4 \%(c: t 63: 37)^{[c]}$

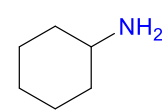

$3 j, 56 \% / 97 \%$ [c] From diphenyl ether<smiles>NC1CCC(CC2CCC(N)CC2)CC1</smiles> 
$3 \mathbf{k}, 99 \%$ From benzyl phenyl ether

3I, 93\% (cc:ct:tt 54:38:9) ${ }^{[\mathrm{dd}]}$

[a] Reaction conditions: phenols $(1,2 \mathrm{mmol})$ in toluene $(20 \mathrm{~mL}), 10 \mathrm{~mol} \% \mathrm{Ni} / \mathrm{Al}_{2} \mathrm{O}_{3}$ with respect to 1,8 bar $\mathrm{H}_{2}$ and 0.5 bar $\mathrm{NH}_{3}(2 \mathrm{a})$ for $3 \mathrm{~h}$ at $160^{\circ} \mathrm{C}$. Conversions $(\mathrm{X})$, yields $(\mathrm{Y})$ and selectivities $(\mathrm{S})$ were determined by GC-FID analysis with $\mathrm{n}$-nonane as the external standard. Diastereomer ratio (c:t) expressed as cis vs. trans. [b] $6 \mathrm{~h}$ [c] $16 \mathrm{~h}$. [d] Bisphenol $\mathrm{F}(\mathbf{1 l}, 1 \mathrm{mmol})$ in tert-amyl methyl ether $(20 \mathrm{~mL}), 10 \mathrm{~mol} \%$ $\mathrm{Ni} / \mathrm{Al}_{2} \mathrm{O}_{3}$ with respect to $-\mathrm{OH}$ groups of $1 \mathrm{l}, 10$ bar $\mathrm{H}_{2}$ and 0.5 bar $\mathrm{NH}_{3}$ for $24 \mathrm{~h}$ at $160^{\circ} \mathrm{C}$. Diastereomer ratio (cc:ct:tt) expressed as cis-cis vs. cis-trans vs. trans-trans.

are often examined as potential bio-based model compounds for the cleavage of these linkages. ${ }^{56-58}$ Inspired by prior reports, ${ }^{48,59}$ the reductive amination of these substrates with ammonia, after hydrogenolysis of the $\mathrm{C}-\mathrm{O}$ bond, afforded the amine products with excellent selectivity $(\mathbf{3} \mathbf{j}$ and $\mathbf{k})$, while benzene and toluene were formed as co-products, respectively. Finally, bisphenol $F$ was successfully converted into 4,4'diaminodicyclohexyl methane $\left(\mathrm{H}_{12} \mathrm{MDA}\right)$, with an excellent yield of $93 \%$ (3I). In the polymer industry, $\mathrm{H}_{12} \mathrm{MDA}$ is frequently used as a curing agent and for the production of diisocyanates.

\section{Amine reactant scope}

The use of amines as the $\mathrm{N}$-source for this reaction, instead of ammonia, was subsequently explored to increase the generality of the Ni-system, resulting in secondary or tertiary cyclohexylamines (Table 3 ). In general, the selectivity to the desired amine product is lower than in previous reactions, as a

Table 3. Reductive amination of phenol with various amines. ${ }^{[a]}$

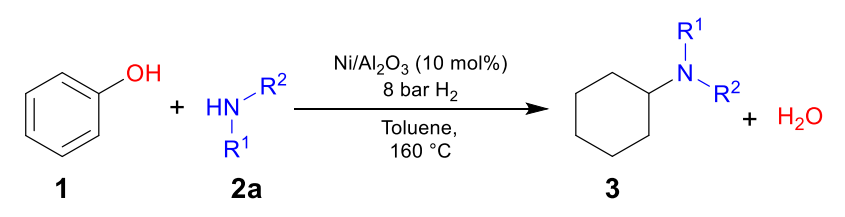

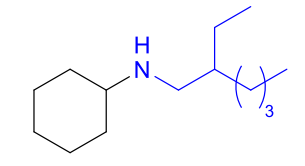

$3 m, 94 \% / 69 \%\left[{ }^{[b]}\right.$

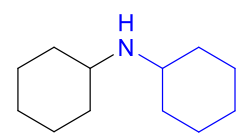

$3 p, 80 \%[c]$

with aniline

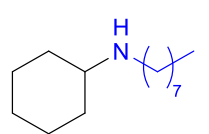

$3 n, 66 \%$

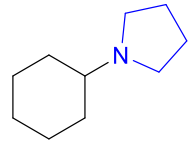

$3 q, 90 \%$

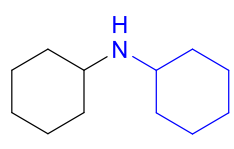

3o, $82 \%[c]$ with cyclohexylamine

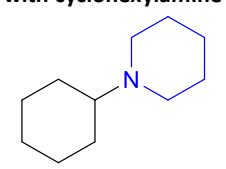

$3 r, 59 \%[d]$ [a] Reaction conditions: phenol $(\mathbf{1 a}, 0.2 \mathrm{mmol})$, amine $(2,0.28 \mathrm{mmol})$ in toluene ( $2 \mathrm{~mL}$ ), $10 \mathrm{~mol} \% \mathrm{Ni} / \mathrm{Al}_{2} \mathrm{O}_{3}$ with respect to phenol, 8 bar $\mathrm{H}_{2}$ for $3 \mathrm{~h}$ at $160{ }^{\circ} \mathrm{C}$ Conversions $(\mathrm{X})$, yields $(\mathrm{Y})$ and selectivities $(\mathrm{S})$ were determined by GC-FID analysis with n-nonane as the external standard. [b] $140^{\circ} \mathrm{C}$. [c] $6 \mathrm{~h}$. [d] $16 \mathrm{~h}$.

noticeable amount of (in this case) undesired primary cyclohexylamine was formed. The latter side product could be formed by a condensation-reduction reaction between the reactive $\mathrm{N}$-substituted cyclohexanimine intermediate and the amine reactant, with the liberation of ammonia. Besides this, two primary amine reactants could generate a secondary amine and ammonia. ${ }^{25,60,61}$ The released ammonia could, in turn, yield the primary cyclohexylamine by reductive amination with cyclohexanone. Therefore, a small excess of 1.4 equivalents of the amine reactant with respect to phenol was used in each reaction. The reductive amination of phenol with 2-ethyl-1hexylamine resulted in the selective formation of the desired secondary amine, with a very high yield of $94 \%(3 \mathrm{~m})$. The temperature of the reaction could be lowered to $140{ }^{\circ} \mathrm{C}$, at the cost of an increased cyclohexanol selectivity. When the linear $n$ octylamine was used, relatively more dimer reactant was formed than with sterically more hindered amine reactants. As a result, ammonia was released and significant amounts of cyclohexylamine ( $23 \%$ yield) were formed, negatively affecting the selectivity towards $N$-octylcyclohexylamine (3n). Next, high yields of dicyclohexylamine were obtained from phenol using cyclohexylamine or aniline as the amine reactant (3o and $\mathbf{3 p}$ ). For the latter, only a small amount of $\mathrm{N}$-cyclohexylaniline was obtained after 6 h of reaction. Finally, cyclic secondary amines (viz., piperidine and pyrrolidine) were also successfully coupled to phenol, resulting in tertiary cyclohexylamines (3q and $\mathbf{r}$ ).

\section{Catalyst stability}

To investigate whether $\mathrm{Ni} / \mathrm{Al}_{2} \mathrm{O}_{3}$ is stable under the employed reaction conditions and if the catalysis truly takes place on the heterogeneous material, filtration and recycling experiments were carried out (Figure 5). Indeed, no further production of cyclohexylamine was observed in the filtrate after removing the
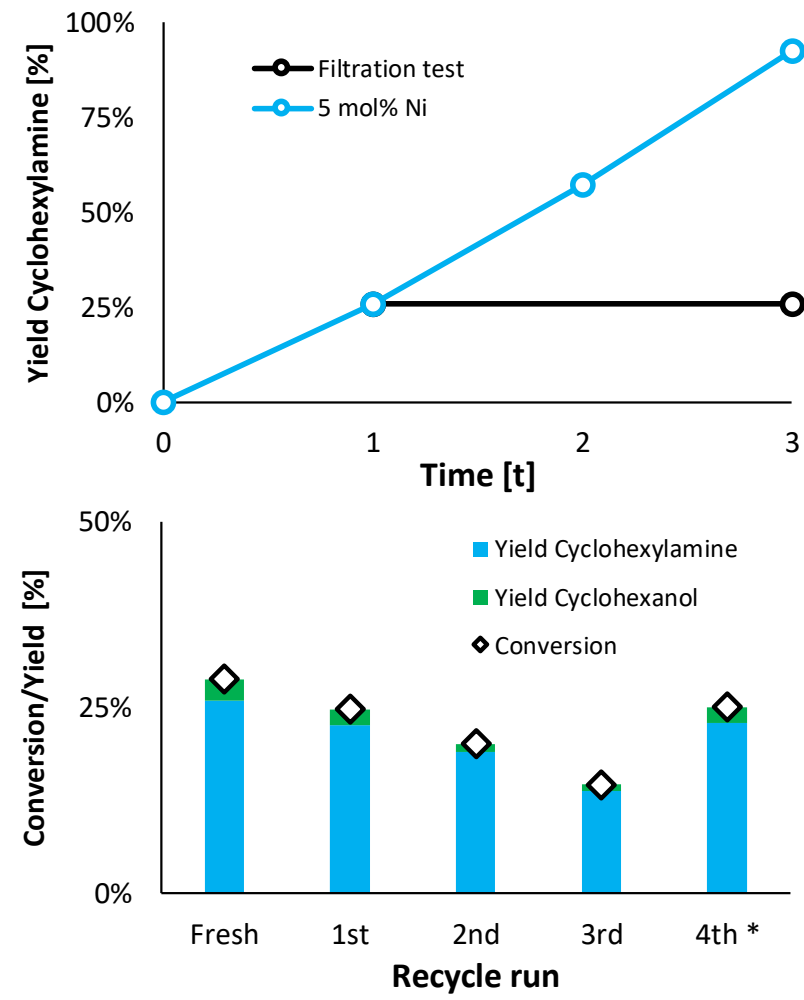

Figure 5. Filtration and recycling experiments. Reaction conditions: phenol $(2 \mathrm{mmol})$ in solvent $(20 \mathrm{~mL}), 5 \mathrm{~mol} \% \mathrm{Ni} / \mathrm{Al}_{2} \mathrm{O}_{3}, 8$ bar $\mathrm{H}_{2}$ and 0.5 bar $\mathrm{NH}_{3}$ for $1 \mathrm{~h}$ at $160{ }^{\circ} \mathrm{C}$. * After re-activation via drying, reduction at $800{ }^{\circ} \mathrm{C}\left(1 \mathrm{~h}, 2{ }^{\circ} \mathrm{C} / \mathrm{min}, 100 \mathrm{~mL} / \mathrm{min} \mathrm{H}_{2}\right)$, passivation $\left(1 \mathrm{~h}, 100 \mathrm{~mL} / \mathrm{min} 1 \% \mathrm{O}_{2}\right.$ in $\mathrm{N}_{2}$ ) at room temperature and replenishing for the lost catalyst. 
catalyst after $1 \mathrm{~h}$ of reaction, suggesting that no active Ni was leached into solution. This was confirmed by ICP-OES analysis as no $\mathrm{Ni}$ was found in the reaction mixture. The $\mathrm{Ni} / \mathrm{Al}_{2} \mathrm{O}_{3}$ catalyst could be reused with only a slight gradual decrease in activity after a simple washing step. This drop is believed to result from the handling losses of the catalyst ( 4 wt\% of the catalyst per recycle), but could also be caused by aggregation of $\mathrm{Ni}$ as the reaction is repeated. In order to assess this, both the fresh and spent catalyst (after one reaction cycle) were studied by powder $X$-ray diffraction (XRD), scanning electron microscopy (SEM) and scanning transmission electron microscopy (STEM) in combination with energy dispersive $\mathrm{X}$-ray spectroscopy (EDX) For both catalysts, the Ni particles were too small to observe the characteristic $\mathrm{Ni}^{0}$ or $\mathrm{NiO}$ peaks ${ }^{62}$ in the XRD patterns (Figure S3). SEM-EDX analysis of different regions of the catalyst revealed
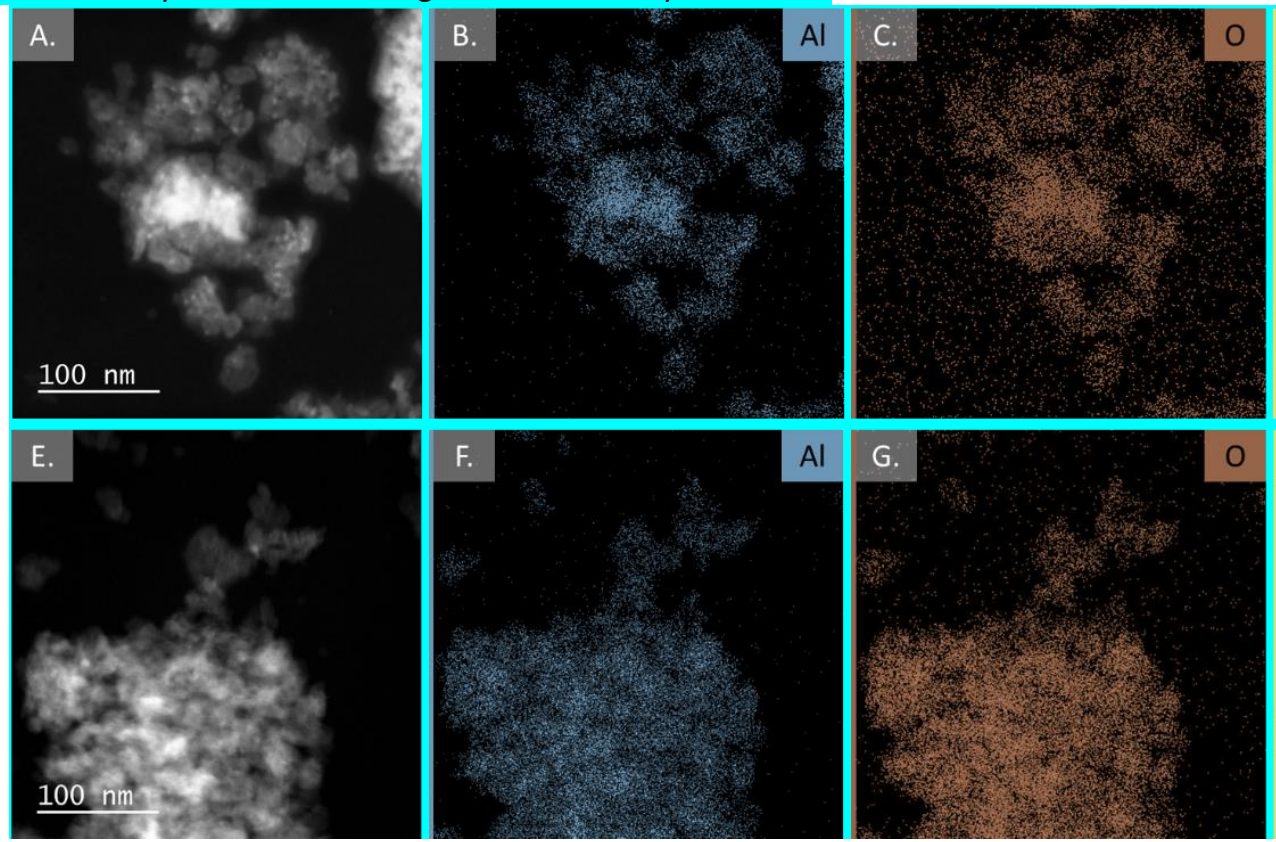

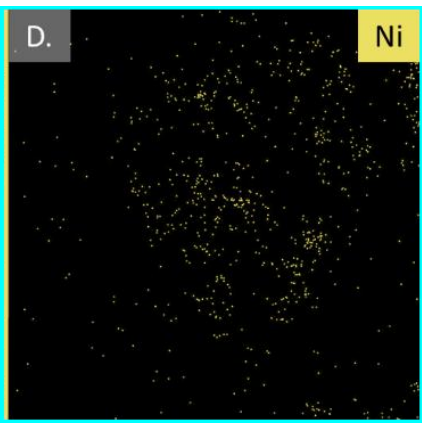

that $\mathrm{Ni}$ was distributed homogeneously on the surface of both samples (Figure S4). Also, the average Ni content of the catalyst after one reaction cycle was found to be around 5 wt\% (Figure S5), which further corroborates that no Ni was leached during reaction. Although in some examples the contrast difference between $\mathrm{Ni}$ and the support is rather low, ${ }^{63,64} \mathrm{Ni}$ particles can be easiliy discerned on the surface of $\mathrm{Al}_{2} \mathrm{O}_{3}$ by STEM imaging (Figure $6 \mathrm{~A}, \mathrm{E}$ and Figure $\mathrm{S6}$ ). The average Ni particle size of the fresh catalyst was determined at $5.63 \mathrm{~nm}$ and this hardly changed after one reaction cycle $\left(d_{a v}=5.97 \mathrm{~nm}\right)$. Elemental mapping via EDX also confirmed the homogeneous distribution of $\mathrm{Ni}$ in both samples (Figure 6B-D, F-H). Finally, we observed

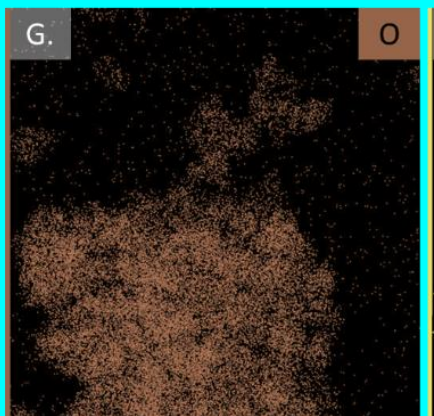

Figure 6. STEM images ( $\mathrm{A}$ and $\mathrm{E}$ ) and EDX elemental mapping ( $\mathrm{B}-\mathrm{D}$ and $\mathrm{F}-\mathrm{H})$ of $5 \mathrm{wt} \% \mathrm{Ni} / \mathrm{Al}_{2} \mathrm{O}_{3}$-fresh $(\mathrm{A}-\mathrm{D})$ and 5 wt $\%$ Ni/Al $\mathrm{O}_{3}$-after one reaction cycle $(\mathrm{E}-\mathrm{H})$.

that the catalytic activity can be largely regained by replenishing for the lost catalyst. These findings seem to suggest that, while $\mathrm{Ni}$ aggregation should not be disregarded, the catalyst handling losses are the main contributor for the drop in activity.

\section{Conclusions}

In conclusion, we demonstrated the first use of a non-noble metal catalytic system for the coupling of phenols with ammonia or amines via reductive amination in the liquid phase. $\mathrm{Ni}$ supported on $\mathrm{Al}_{2} \mathrm{O}_{3}$ was identified as a suitable catalyst for this reaction, resulting in the formation of cyclohexylamine with a very high selectivity. The influence of the acid-base properties of the catalyst was investigated by FTIR spectroscopy using cyclohexylamine as the probe, elucidating the importance of a moderate acidity of the support material. The effect of other reaction parameters such as the solvent, the $\mathrm{NH}_{3}$ and $\mathrm{H}_{2}$ partial pressures was extensively investigated and brought into practice in the amination of different (biobased) phenols or phenol-derivatives to primary cyclohexylamines. Finally, phenol was successfully coupled with amines to secondary and tertiary amines, expanding the reactant scope and applicability of the $\mathrm{Ni}$ catalyst.

\section{Experimental}

\section{Catalyst synthesis}

High surface area spinel-type materials, $\mathrm{MgAl}_{2} \mathrm{O}_{4}, \mathrm{BaAl}_{2} \mathrm{O}_{4}$ and $\mathrm{CaAl}_{2} \mathrm{O}_{4}$, were synthesized according to literature. ${ }^{65} \mathrm{An}$ aqueous polyvinyl (PVA) solution was prepared by dissolving 2 wt $\%$ of PVA in deionized water at $75{ }^{\circ} \mathrm{C}$ for $30 \mathrm{~min}$. Stoichiometric amounts of $\mathrm{Ba}\left(\mathrm{NO}_{3}\right)_{2}, \mathrm{Mg}\left(\mathrm{NO}_{3}\right)_{2} \cdot 6 \mathrm{H}_{2} \mathrm{O}$ or $\mathrm{Ca}\left(\mathrm{NO}_{3}\right)_{2} \cdot 4 \mathrm{H}_{2} \mathrm{O}$ and $\mathrm{Al}\left(\mathrm{NO}_{3}\right)_{3} \cdot 9 \mathrm{H}_{2} \mathrm{O}$ were added to this solution $\left(\mathrm{M}^{2+} / \mathrm{Al}^{3+}=0.5\right)$, with a total metal ions to PVA monomer ratio of 1 . The mixture was stirred at room temperature for $1 \mathrm{~h}$. The $\mathrm{pH}$ was adjusted to 10 with aqueous ammonia ( $25 \mathrm{wt} \%$ in $\mathrm{H}_{2} \mathrm{O}$ ). Next, the resulting gel was thoroughly mixed by mechanical agitation for $3 \mathrm{~h}$ and aged overnight at room temperature. The precipitate was obtained 
after filtration and subsequent washing with deionized water and lyophilization, leading to a fine powder. Finally, the spinel was obtained after calcination in air at $800^{\circ} \mathrm{C}\left(5^{\circ} \mathrm{C} / \mathrm{min}\right)$ for $8 \mathrm{~h}$. Self-prepared supported nickel catalysts ( $5 \mathrm{wt} \% \mathrm{Ni}$ on support) were prepared by incipient wetness impregnation. In a typical procedure, the supporting material was impregnated with an aqueous solution of $\mathrm{Ni}\left(\mathrm{NO}_{3}\right)_{2} \cdot 6 \mathrm{H}_{2} \mathrm{O}$ in deionized water. The impregnated supports were then dried overnight at $60{ }^{\circ} \mathrm{C}$, granulated to particles $(250-500 \mu \mathrm{m})$, reduced $\left(1 \mathrm{~h}, 2^{\circ} \mathrm{C} / \mathrm{min}\right.$, $\left.100 \mathrm{~mL} / \mathrm{min} \mathrm{H}_{2}\right)$ in a quartz $\mathrm{U}$-tube and finally passivated $(1 \mathrm{~h}$, $100 \mathrm{~mL} / \mathrm{min} 1 \% \mathrm{O}_{2}$ in $\mathrm{N}_{2}$ ) at room temperature. The reduction temperature was based on temperature-programmed reduction (TPR) profiles found in literature. ${ }^{36,66-69}$ For $y-\mathrm{Al}_{2} \mathrm{O}_{3}$ and $\mathrm{Al}_{2} \mathrm{O}_{3}$, the reduction temperature was set at $800{ }^{\circ} \mathrm{C}$, while all other materials $\left(\mathrm{Ni}\right.$ on $\mathrm{ZrO}_{2}, \mathrm{TiO}_{2}, \mathrm{SiO}_{2}, \mathrm{SiO}_{2}-\mathrm{Al}_{2} \mathrm{O}_{3}$ and $\mathrm{MgAl}_{2} \mathrm{O}_{4}$ ) were reduced at $600{ }^{\circ} \mathrm{C}$, unless stated otherwise. All catalysts were stored under an Ar atmosphere.

\section{Amination reactions}

All amination reactions with ammonia were performed in highpressure stainless steel Premex Vivor batch reactors $(60 \mathrm{~mL})$ equipped with a digital pressure sensor (+/- 0.01 bar accuracy). In a standard reaction, the reactor was loaded with phenol (2 $\mathrm{mmol})$ in toluene $(20 \mathrm{~mL})$, catalyst $(10 \mathrm{~mol} \% \mathrm{Ni}$ relative to phenol) and a magnetic stirring rod. After purging with $\mathrm{N}_{2}$ and $\mathrm{NH}_{3}$, the reactor was subsequently pressurized with 1 bar $\mathrm{NH}_{3}$ and 4 bar $\mathrm{H}_{2}$ at room temperature. Next, the reactor was heated at an internal temperature of $160^{\circ} \mathrm{C}$ under continuous agitation (550 rpm) for $3 \mathrm{~h}$. After the reaction, the reactor was cooled down in ice and the solid catalyst was separated from the reaction mixture via centrifugation (3500 rpm). An analogous procedure was followed for the upscaled experiment, except that phenol $(50 \mathrm{mmol})$ in toluene $(100 \mathrm{~mL})$ and catalyst $(10$ mol\% Ni relative to phenol) were added to a Parr batch reactor $(600 \mathrm{~mL})$. For the reductive amination with different amine reactants, a stainless steel autoclave $(11 \mathrm{~mL})$ was typically filled with phenol $(0.2 \mathrm{mmol})$ in toluene $(2 \mathrm{~mL})$, amine $(0.28 \mathrm{mmol})$, catalyst (10 mol\% Ni relative to phenol) and a magnetic stirring rod. After purging with $\mathrm{N}_{2}$ and $\mathrm{H}_{2}$, the reactor was pressurized with 8 bar $\mathrm{H}_{2}$ at room temperature. Next, the reactor was heated in a heating block at $160^{\circ} \mathrm{C}$ under continuous agitation $(550 \mathrm{rpm})$ for $3 \mathrm{~h}$. After the reaction, the reactor was cooled down in ice and the solid catalyst was separated from the reaction mixture via filtration (PTFE filter). Finally, the reaction mixtures were analyzed by GC-FID with n-nonane as external standard and by GC-MS. In the recycling experiments, the catalyst was thoroughly washed with toluene before each cycle, whilst minimizing exposure of $\mathrm{Ni}$ to air. Approximately $4 \mathrm{wt} \%$ of the original catalyst was lost in each recycle. For the $4^{\text {th }}$ cycle, $\mathrm{Ni} / \mathrm{Al}_{2} \mathrm{O}_{3}$ was re-activated with $\mathrm{H}_{2}\left(800{ }^{\circ} \mathrm{C}, 1 \mathrm{~h}, 2{ }^{\circ} \mathrm{C} / \mathrm{min}, 100\right.$ $\mathrm{mL} / \mathrm{min} \mathrm{H}_{2}$ ), passivated $\left(1 \mathrm{~h}, 100 \mathrm{~mL} / \mathrm{min} 1 \% \mathrm{O}_{2}\right.$ in $\mathrm{N}_{2}$ ) at room temperature and replenished for the lost catalyst $(14.1 \mathrm{mg})$.

\section{Catalyst characterization}

Cyclohexylamine adsorption followed by Fourier transform infrared (FTIR) spectroscopy was used to study the acidity of selected supports and their interaction with the probe molecule using a Nicolet 6700 FTIR spectrometer equipped with a DTGS detector (128 scans, $2 \mathrm{~cm}^{-1}$ resolution). To this end, a selfsupporting wafer of approximately $10 \mathrm{mg} / \mathrm{cm}^{2}$ was placed in a cell under vacuum and activated at $400{ }^{\circ} \mathrm{C}$ for $1 \mathrm{~h}$. The cell was then cooled down and reference spectra were recorded at 50 ${ }^{\circ} \mathrm{C}, 100{ }^{\circ} \mathrm{C}, 150{ }^{\circ} \mathrm{C}$ and $250{ }^{\circ} \mathrm{C}$. After this, cyclohexylamine $(28$ mbar) was allowed to be adsorbed on the wafer at $50{ }^{\circ} \mathrm{C}$ until saturation. The physisorbed cyclohexylamine was removed by evacuation under vacuum for $0.5 \mathrm{~h}$ before collecting the FTIR spectra at $50{ }^{\circ} \mathrm{C}, 100{ }^{\circ} \mathrm{C}, 150{ }^{\circ} \mathrm{C}, 200{ }^{\circ} \mathrm{C}$ and $250{ }^{\circ} \mathrm{C}$. Additional FTIR spectra of $\mathrm{KBr}$ wafers ( $1 \mathrm{wt} \%$ of sample) were collected on a Bruker IFS 66 v/S Vacuum FTIR spectrometer ( 128 scans, $4 \mathrm{~cm}$ 1 resolution), for $\mathrm{ZrO}_{2}$ and for $\mathrm{ZrO}_{2}$ after adsorption of aniline. The leaching of $\mathrm{Ni}$ into the solution was investigated by ICP-OES at $231.604 \mathrm{~nm}$ using a Varian 720-ES equipped with a doublepass glass cyclonic spray chamber, a Sea Spray concentric glass nebulizer and a high solids torch, and applying the calibration curve method. For this, the organic solvent was removed from the supernatant of the reaction mixture $(1 \mathrm{~mL})$ by rotary evaporation. Next, $1.5 \mathrm{~mL}$ of aqua regia was added to dissolve the $\mathrm{Ni}$ in the sample overnight. Finally, $0.5 \mathrm{~mL}$ of the resulting mixture was diluted with $9.5 \mathrm{~mL}$ of $0.42 \mathrm{~N} \mathrm{HNO}_{3}$ in Milli-Q water. STEM images were collected with a JEOL ARM200F microscope equipped with a probe aberration corrector and a coldFEG operated at $200 \mathrm{kV}$. EDX elemental mappings were performed using a JEOL Centurio with a solid angle of $0.98 \mathrm{Sr}$ and a detection area of $100 \mathrm{~mm}^{2}$. For this, the samples were deposited on standard 300 mesh Cu grids with a holey and thin carbon film coating from an ethanol dispersion.

\section{Conflicts of interest}

There are no conflicts to declare.

\section{Acknowledgements}

T. C. and C. V. G. thank the Fonds Wetenschappelijk Onderzoek (FWO-Vlaanderen) for the (post-)doctoral fellowships. D.E.D.V. acknowledges the FWO for research project funding, the Flemish government for long-term structural funding through the Methusalem program, and EoS (FWO-FNRS) for financial support. I. V. recognizes the Hercules project (AKUL/13/19) for financial aid. Finally, the authors thank Ka Yan Cheung for the help with SEM-EDX measurements.

\section{Notes and references}

1 P. Roose, K. Eller, E. Henkes, R. Rossbacher and H. Höke, in Ullmann's Encyclopedia of Industrial Chemistry, Wiley-VCH Verlag GmbH \& Co. KGaA, 2015, pp. 1-50.

2 H. Engels, H. Pirkl, R. Albers, R. W. Albach, J. Krause, A. Hoffmann, H. Casselmann and J. Dormish, Angew. Chem. Int. Ed., 2013, 9422-9441.

3 S. A. Lawrence, Amines: Synthesis, Properties and Applications, Cambridge University Press, Cambridge, 2005.

4 J. Royer, Chiral Amine Synthesis. Methods, Developments and Applications, Wiley-VCH, 2010. 
5 H. U. Blaser, H. Steiner and M. Studer, ChemCatChem, 2009, 1, 210-221.

6 S. Geun, V. Mishra, J. Ku, B. Kim, H. Sik, Y. Suh, H. Lee, H. Seok and Y. Jin, Catal. Commun., 2014, 43, 79-83.

7 P. Tomkins, E. Gebauer-Henke, W. Leitner and T. E. Müller, ACS Catal., 2015, 5, 203-209.

8 L. Wang, J. Zhang, H. Wang, Y. Shao, X. Liu, Y. Wang, J. P. Lewis and F. Xiao, ACS Catal., 2016, 6, 4110-4116.

9 J. Zhang, L. Wang, Y. Shao, Y. Wang, B. C. Gates and F. Xiao, Angew. Chem. Int. Ed., 2017, 56, 9747-9751.

10 H. Greenfield, J. Org. Chem., 1964, 29, 3082-3084.

11 S. X. Huang, D. A. Fischer and J. L. Gland, J. Phys. Chem. A, 1996, 3654, 10223-10234.

12 E. Gebauer-Henke, P. Tomkins, W. Leitner and T. E. Müller, ChemCatChem, 2014, 6, 2910-2917.

13 A. S. Guram, R. A. Rennels and S. L. Buchwald, Angew. Chem. Int. Ed., 1995, 34, 1348-1350.

14 J. X. Qiao and P. Y. S. Lam, in Boronic Acids: Preparation and Applications in Organic Synthesis, Medicine and Materials, Wiley-VCH Verlag GmbH \& Co. KGaA., 2011, pp. 315-361.

15 S. Bähn, S. Imm, L. Neubert, M. Zhang, H. Neumann and M. Beller, ChemCatChem, 2011, 3, 1853-1864.

16 B. Galabov, D. Nalbantova, P. V. R. Schleyer and H. F. Schaefer, Acc. Chem. Res., 2016, 49, 1191-1199.

17 R. Dorel, C. P. Grugel and A. M. Haydl, Angew. Chem. Int. Ed. 2019, 58, 2-14.

$18 \mathrm{~K}$. Weissermel and H.-J. Arpe, Industrial Organic Chemistry, Wiley-VCH Verlag GmbH, 2003.

19 J. Zakzeski, P. C. A. Bruijnincx, A. L. Jongerius and B. M. Weckhuysen, Chem. Rev., 2010, 110, 3552-3599.

20 M. Weber, M. Weber and M. Kleine-Boymann, in Ullmann's Encyclopedia of Industrial Chemistry, Wiley-VCH Verlag GmbH \& Co. KGaA, 2004, pp. 503-519.

21 Z. Chen, H. Zeng, H. Gong, H. Wang and C. Li, Chem. Sci., 2015, 6, 4174-4178.

22 V. R. Jumde, E. Petricci, C. Petrucci, N. Santillo, M. Taddei and L. Vaccaro, Org. Lett., 2015, 17, 3990-3993.

23 Z. Qiu, J.-S. Li and C.-J. Li, Chem. Sci., 2017, 8, 6954-6958.

24 Z. Chen, H. Zeng, S. A. Girard, F. Wang, N. Chen and C. J. Li, Angew. Chem. - Int. Ed., 2015, 54, 14487-14491.

25 P. Tomkins, C. Valgaeren, K. Adriaensen, T. Cuypers and D. E. De Vos, J. Catal., 2019, 371, 207-213.

26 T. Cuypers, P. Tomkins and D. E. De Vos, Catal. Sci. Technol., 2018, 8, 2519-2523.

27 P. Tomkins, C. Valgaeren, K. Adriaensen, T. Cuypers and D. E. De Vos, ChemCatChem., 2018, 10, 3689-3693.

28 Z. Qiu, L. Lv, J. Li, C.-C. Li and C.-J. Li, Chem. Sci., 2019, 10, 4775-4781.

29 K. Shimizu, K. Kon, W. Onodera, H. Yamazaki and J. N. Kondo, ACS Catal., 2013, 3, 112-117.

30 K. Shimizu, N. Imaiida, K. Kon, S. M. A. Hakim Siddiki and A. Satsuma, ACS Catal., 2013, 3, 998-1005.

31 K. Shimizu, S. Kanno, K. Kon, S. M. A. Hakim Siddiki, H. Tanaka and Y. Sakata, Catal. Today, 2014, 232, 134-138.

32 W. Wang, Q. Yu, Q. Zhang, S. Mei, J. Yuan, F. Zhao, J. Yang and J. Lu, ChemistrySelect, 2017, 2, 8818-8823.

33 J. He, X. H. Lu, Y. Shen, R. Jing, R. F. Nie, D. Zhou and Q. H. Xia, Mol. Catal., 2017, 440, 87-95.

34 A. Li, K. Shen, J. Chen, Z. Li and Y. Li, Chem. Eng. Sci., 2017, 166, 66-76.

35 A. Yuk, K. Leung, K. Hellgardt, K. Kuok and M. Hii, ACS Sustain. Chem. Eng., 2018, 6, 5479-5484.

36 N. Hadian, M. Rezaei, Z. Mosayebi and F. Meshkani, J. Nat. Gas Chem., 2012, 21, 200-206.

37 M. Chalid, H. J. Heeres and A. A. Broekhuis, Procedia Chem., 2012, 4, 260-267.
38 D. Prat, A. Wells, J. Hayler, H. Sneddon, C. R. McElroy, S. AbouShehada and P. J. Dunn, Green Chem., 2016, 18, 288-296.

39 C. M. Alder, J. D. Hayler, R. Henderson, A. Redman, L. Shukla, L. E. Shuster and H. F. Sneddon, Green Chem., 2016, 4, 11661169.

40 G. Busca, Phys. Chem. Chem. Phys., 1999, 1, 723-736.

41 N. C. Jeong, J. S. Lee, E. L. Tae, Y. J. Lee and K. B. Yoon, Angew. Chem. Int. Ed., 2008, 47, 10128-10132.

42 F. De Schouwer, T. Cuypers, L. Claes and D. E. De Vos, Green Chem., 2017, 19, 1866-1876.

43 M. Tamura, K. Shimizu and A. Satsuma, Appl. Catal. A Gen. 2012, 433-434, 135-145.

44 R. Sokoll, H. Hobert and I. Schmuck, J. Catal., 1990, 284, 276284.

45 H. K. Hall and R. B. Bates, Tetrahedron Lett., 2012, 53, 18301832.

46 Y. Yoon, R. Rousseau, R. S. Weber, D. Mei and J. A. Lercher, ACS Catal., 2014, 136, 10287-10298

47 X. Kong, Y. Gong, S. Mao and Y. Wang, ChemNanoMat, 2018, $4,432-450$

48 D. Cao, H. Zeng and C.-J. Li, ACS Catal., 2018, 8, 8873-8878.

49 N. Yoshimura, I. Moritani, T. Shimamura and S. Murahashi, J. Am. Chem. Soc., 1973, 95, 3038-3039.

50 S.-I. Murahashi, N. Yoshimura, T. Sumiyama and T. Kojima, J. Am. Chem. Soc., 1983, 5002-5011.

51 S. P. Bawane and S. B. Sawant, Chem. Eng. J., 2004, 103, 1319.

52 G. Xu, J. Guo, Y. Zhang, Y. Fu, J. Chen, L. Ma and Q. Guo, ChemCatChem, 2015, 7, 2485-2492.

53 J. Mao, J. Zhou, Z. Xia, Z. Wang, Z. Xu, W. Xu, P. Yan, K. Liu, X. Guo and Z. C. Zhang, ACS Catal., 2016, 7, 695-705.

54 X. Huang, J. Ludenhoff, M. Dirks, X. Ouyang, M. D. Boot and E. J. M. Hensen, ACS Catal., 2018, 8, 11184-11190.

55 Y. Wang, J. Yao, H. Li, D. Su and M. Antonietti, J. Am. Chem. Soc., 2011, 133, 2362-2365.

56 A. G. Sergeev and J. F. Hartwig, Science, 2011, 332, 439-443.

57 A. G. Sergeev, J. D. Webb and J. F. Hartwig, J. Am. Chem. Soc. 2012, 134, 20226-20229.

58 J. He, C. Zhao and J. A. Lercher, J. Am. Chem. Soc., 2012, 134 20768-20775.

59 H. Zeng, D. Cao, Z. Qiu and C.-J. Li, Angew. Chem. Int. Ed., 2018, 57, 1-7.

60 K. Taniguchi, X. Jin, K. Yamaguchi and N. Mizuno, Chem Commun., 2015, 51, 14969-15082.

61 K. Taniguchi, X. Jin, K. Yamaguchi, K. Nozaki and N. Mizuno, Chem. Sci., 2017, 8, 2131-214.

62 G. Li, L. Hu and J. M. Hill, Appl. Catal. A Gen., 2006, 301, 1624

63 W. Schutyser, S. Van Den Bosch, J. Dijkmans, S. Turner, M. Meledina, G. Van Tendeloo, D. P. Debecker and B. F. Sels, ChemSusChem, 2015, 8, 1805-1818.

64 J. Verduyckt, A. Geers, B. Claes, S. Eyley, C. Van Goethem, I. Stassen, S. Smolders, R. Ameloot, I. Vankelecom, W. Thielemans and D. De Vos, Green Chem., 2017, 19, 46424650.

65 J. Guo, H. Lou, H. Zhao, X. Wang and X. Zheng, Mater. Lett., 2004, 58, 1920-1923.

66 A. M. Ruppert, M. Niewiadomski, J. Grams and W. Kwapiński, Appl. Catal. B Environ., 2014, 145, 85-90.

67 M. Rezaei, S. M. Alavi, S. Sahebdelfar and Z. F. Yan, Mater. Lett., 2007, 61, 2628-2631.

68 S. Chettibi, N. Keghouche, Y. Benguedouar, M. M. Bettahar and J. Belloni, Catal. Letters, 2013, 143, 1166-1174.

69 R. Wang, Y. Li, R. Shi and M. Yang, J. Mol. Catal. A Chem., 2011, 344, 122-127. 